\title{
Antimicrobial Properties of Averrhoa bilimbi Extracts at Different Maturity Stages
}

Seri Intan Mokhtar* and Nur Ain Abd Aziz

Faculty of Agro Based Industry, Universiti Malaysia Kelantan, Jeli Campus, Kelantan, Malaysia

*Corresponding author: Seri Intan Mokhtar Faculty of Agro Based Industry, Universiti Malaysia Kelantan, Jeli Campus, Locked Bag No.100, 17600 Jeli, Kelantan, Malaysia, Tel: 09-9477158/2158; E-mail: intan@umk.edu.my

Rec Date: Feb 09 2016; Acc Date: Jun 29 2016; Pub Date: Jul 062016

Copyright: ( 2016 Mokhtar SI, et al. This is an open-access article distributed under the terms of the Creative Commons Attribution License, which permits unrestricted use, distribution, and reproduction in any medium, provided the original author and source are credited.

\begin{abstract}
In the present study, the water extracts of Averrhoa bilimbi at different maturity stages were evaluated to investigate antimicrobial activity against two Gram positive and three Gram negative bacteria by disc diffusion and broth dilution assays. All of the bacterial isolates showed varying degrees of sensitivity towards A. bilimbi extracts. For disc diffusion assay, Gram positive bacterium, Staphylococcus aureus was more sensitive to the extract than Bacillus cereus with inhibition zone of $9.3 \mathrm{~mm}$ (young fruit), $12.3 \mathrm{~mm}$ (mature fruit) and $10 \mathrm{~mm}$ (ripe fruit). The findings also demonstrated that the extracts have stronger antimicrobial effects against Gram negative bacteria, Salmonella spp. with inhibition zone of $12 \mathrm{~mm}$ at young fruit, $11 \mathrm{~mm}$ at mature fruit and $9.3 \mathrm{~mm}$ at ripe fruit than Escherichia coli and Pseudomonas aeruginosa. From broth dilution method, the MIC of extracts were $0.125 \mathrm{gml}^{-1}$ at young stage, $0.25 \mathrm{gml}^{-1}$ at mature stage and $0.5 \mathrm{gml}^{-1}$ at ripe stage against Escherichia coli while $0.25 \mathrm{gml}^{-1}$ at either young or ripe stage and $0.125 \mathrm{gml}^{-1}$ at mature stage for $S$. aureus. The results suggested that the antimicrobial properties are influenced by the maturity stages of the fruit especially at early stage of maturity.
\end{abstract}

Keywords: Averrhoa bilimbi; Maturity stages; Gram positive bacteria; Gram negative bacteria

\section{Introduction}

Natural products are valuable sources of structurally diverse chemical compounds. Many such compounds have been isolated from different part of sources and applied into clinical medical practice [1]. Among the natural resources, fruits and vegetables have been widely studied for the discovery of antimicrobial, anticancer, antioxidants, anti-inflammatory and others [2]. Recently, underutilized fruits have drawn attention of many researchers as a natural source of treatment for curing various diseases. Moreover, antibacterial activities of extracts have been reported by many scientists $[3,4]$.

Averrhoa bilimbi from Oxalidaceae family is an edible and underutilized fruits, native from South-East Asia and cultivated in some parts of India [1]. Traditionally, the leaves are used as paste on itches, swelling, skin eruptions, cough, sites of poisonous, etc. The decoction of fruits is also treating inflammatory conditions including hepatitis, fever and diarrhea. In some villages in India, the fruit has been used in folk medicine to control obesity [5]. In Java, the fruits combined with pepper are eaten that cause sweating when people are feeling under the weather. Usually, mixture of fruits are being harvest and used together, no study has been done to determine the most effective fruits maturity to be used for medicinal purpose. Hence the present study has been aimed to investigate the effect of antimicrobial activities of $A$. bilimbi extract at different maturity stages against some bacterial isolates.

\section{Materials and Methods}

\section{Fruits extraction}

A. bilimbi fruits at various maturity stages were purchased from local villagers in Machang and Jeli districts in Kelantan, Malaysia. Fruits with good condition (colour, size, shape, no defects and decay) at each maturity stages were selected. The ripening stage of the fruits was distinguished through physical observation. To obtain fruits juice, water extraction method was conducted. Selected fruits according to their maturity were cut into halves, and $50 \mathrm{~g}$ fruit were weighed and blended with $100 \mathrm{ml}$ water. To obtain clear juice, the blended fruits were filtered through a muslin cloth or a stainless steel filter with small porosity. The filtered fruit extracts were immediately stored in freezer at $0^{\circ} \mathrm{C}$.

\section{Microorganisms}

Five species of bacteria used in this study consists of two Grampositive (Staphylococcus aureus, Bacillus cereus), three Gram-negative (Pseudomonas aeruginosa, E. coli and Salmonella spp.) were obtained from Director of Veterinary Research Institute, Ipoh. The test bacteria was sub-cultured into nutrient agar (Baker and Palister, 1998) and maintained at $4^{\circ} \mathrm{C}$ respectively.

\section{Culture preparation}

All the bacteria were sub-cultured on nutrient agar for inoculation. Single colony of each subculture bacteria was inoculated in $10 \mathrm{ml} \mathrm{LB}$ broth and incubated at $37^{\circ} \mathrm{C}$ for 24 hours on incubator shaker at 150 $\mathrm{rpm}$. These stock cultures were kept at $4^{\circ} \mathrm{C}$ for antimicrobial assays [6]. 
Page 2 of 3

\section{Screening of fruit extracts using disc diffusion assay}

The disc diffusion test was performed using a modified Kirby-Bauer method [7]. $100 \mu \mathrm{l}$ of the microbial suspension was added and swabbed onto the surface of nutrient agar (NA). The plates were allowed to dry at room temperature within 15 minutes. Next, $10 \mu \mathrm{l}$ of fruit extract with concentration of $0.5 \mathrm{gml}^{-1}$ were immersed into a sterile $6 \mathrm{~mm}$ paper discs and allowed to dry for 1 hour in a laminar flow hood. Dry discs were aseptically placed on NA. Disc with Ampicillin was used as a control. The plates were incubated at $37^{\circ} \mathrm{C}$ for $24 \mathrm{~h}$. Antimicrobial activity was evaluated by measuring inhibition zone diameters.

\section{Determination of minimum inhibitory concentrations using broth dilution assay}

The minimum inhibitory concentrations (MICs) of all fruit extracts against 5 microbial strains were determined using broth dilution assay. The fruit extracts were diluted using serial two fold dilution method to obtain seven different concentrations starting with $0.5 \mathrm{mgml}^{-1}$ and $0.008 \mathrm{mgml}^{-1}$ [8]. Then, $1 \mathrm{ml}$ of the microbial suspension of $S$. aureus and E. coli $\left(2 \times 106 \mathrm{cfuml}^{-1}\right)$ were added to each test tube [9]. The control test tube containing medium only was used to confirm the sterility of the medium. All culture test tubes were incubated at $37^{\circ} \mathrm{C}$ for 24 hours. Afterwards, incubation tubes were observed for changes in turbidity as an indicator of growth. The lowest concentration that did not permit any visible growth was considered as MIC [10].

\section{Results and Discussions}

\section{Disc diffusion assay}

The zones of inhibition observed in the disc diffusion assay are shown in the Table 1 . Zone of inhibition $\geq 8 \mathrm{~mm}$ were considered as inhibitions resulting from considerable antimicrobial activity.

Diameter zone of inhibition interpretation: $\leq 11 \mathrm{~mm}$ (resistant), $12-13 \mathrm{~mm}$ (intermediate), $\geq 14 \mathrm{~mm}$ (susceptible).

\begin{tabular}{|c|c|c|c|c|c|}
\hline \multirow[t]{3}{*}{ Bacteria } & \multicolumn{5}{|c|}{ Zone of inhibition $(\mathrm{mm})$} \\
\hline & & \multicolumn{3}{|c|}{ Averrhoa bilimbi Extracts* } & \multirow{2}{*}{$\begin{array}{l}\text { Standard } \\
\text { antibiotics }\end{array}$} \\
\hline & & Young & Mature & Ripe & \\
\hline \multirow{2}{*}{$\begin{array}{l}\text { Gram } \\
\text { positive }\end{array}$} & S. aureus & 9.3 & 12.3 & 10 & 18.7 \\
\hline & B. cereus & 8 & 9.7 & 9 & 8.3 \\
\hline \multirow{3}{*}{$\begin{array}{l}\text { Gram } \\
\text { negative }\end{array}$} & E. coli & 10.3 & 10 & 8 & 14 \\
\hline & $P$. aeruginosa & 9 & 8.7 & 8.3 & 12.3 \\
\hline & $\begin{array}{l}\text { Salmonella } \\
\text { spp. }\end{array}$ & 12 & 11 & 9.3 & 16.7 \\
\hline \multicolumn{6}{|c|}{${ }^{*}$ extracts concentration $0.5 \mathrm{gml}^{-1}$} \\
\hline
\end{tabular}

Table 1: Zone of inhibition of $A$. bilimbi extract at different maturity stages against test bacteria on NA using disc diffusion assay.

Mature fruit extract of A. bilimbi exhibited a maximum inhibition zone of $12.3 \mathrm{~mm}$ and $9.7 \mathrm{~mm}$ against both Gram positive bacteria of $S$. aureus and $B$. cereus. Young fruit extracts showed a maximum zone of inhibition against Salmonella spp. $(12 \mathrm{~mm})$ followed by mature stage $(11 \mathrm{~mm})$ and ripe stage $(9.3 \mathrm{~mm})$. Young and mature stages of extracts showed a very good antimicrobial activity when compared to ripe stage.

\section{The minimum inhibitory concentrations (MIC) values of extracts}

Table 2 show the MIC values of $A$. bilimbi extracts against $E$. coli increases as the fruits ripen. Young stage of $A$. bilimbi was found to be most effective against E. coli with MIC value of $0.125 \mathrm{gml}^{-1}$. However, mature fruit of extract was more effective than other stages as indicated by its lower MIC $\left(0.125 \mathrm{gml}^{-1}\right)$ values against $S$. aureus.

\begin{tabular}{|c|c|c|c|c|c|c|c|c|c|}
\hline \multirow{2}{*}{ Bacteria } & \multirow{2}{*}{ Maturity stages } & \multicolumn{7}{|c|}{ Concentration of extract $\left(\mathrm{gml}^{-1}\right)$} & \multirow{3}{*}{$\begin{array}{l}\text { MIC }\left(\mathrm{gml}^{-1}\right) \\
0.125\end{array}$} \\
\hline & & 0.5 & 0.25 & 0.125 & 0.063 & 0.031 & 0.016 & 0.008 & \\
\hline \multirow{3}{*}{ E. coli } & Young & - & - & - & + & + & + & - & \\
\hline & Mature & - & - & + & + & + & - & - & 0.25 \\
\hline & Ripe & - & + & + & + & + & + & + & 0.5 \\
\hline \multirow{3}{*}{ S. aureus } & Young & - & - & + & + & + & - & - & 0.25 \\
\hline & Mature & - & - & - & + & + & - & + & 0.125 \\
\hline & Ripe & - & - & + & + & + & - & - & 0.25 \\
\hline
\end{tabular}

Table 2: MIC value for extracts at each maturity stages against Gram negative bacteria of E. coli and Gram positive bacteria of $S$. aureus.

\section{Conclusions}

A. bilimbi fruit extracts at all stages of ripening has some inhibitory activities against selected bacterial strains. However, extracts from younger fruits are more effective against the bacteria. The high content of bioactive compounds in the first stages of fruits might contribute to the antimicrobial properties of the fruits [11]. A. bilimbi contains oxalic acid which is strong acid that might have an action on bacterial 
Citation: $\quad$ Mokhtar SI, Aziz NAA (2016) Antimicrobial Properties of Averrhoa bilimbi Extracts at Different Maturity Stages. J Med Microb Diagn 5:

Page 3 of 3

growth; This is supported by [12], who reported that the content of oxalic acid in Averrhoa species can become a potent source of antioxidant and antimicrobial against $S$. aureus. Further studies need to be done to determine different type of compounds being produce at different maturity stages in order to support this finding.

\section{References}

1. Sumas D (2012) Antimicrobial and Antioxidant of Green and Ripe Fruits of Averrhoa carambola LINN and Zizyphus mauritiana LAM. Asian J Pharm Clin Res 5: 102-105.

2. de Smet PA (1997) The Role of Plant Derived Drugs and Herbal Medicines in Healthcare. Drugs 54: 801-840.

3. Selvam AP, Mokhtar SI, Abd Aziz NA, Mokhtar SB (2013) Traditional method of fish treatment; microbial count and palatability studies on spoiled fish. MJM 9: 135-139.

4. Hussain A, Zaman MK, Ramteke M (2010) Antibacterial Activity of Trunk Bark of Alstonia scholaris. Asian J Pharmaceu Clin Res 3: 46-47.

5. Anitha R, Geetha RV, Lakshmi T (2011) Averrhoa bilimbi Linn- Nature's Drug Store-A Pharmacological Review. Int J Drug Dev \& Res 3:101-106.
6. Supriya D, Ashish S, Ankit S, Nirmala G, Agrawal R C (2012) Evaluation of in-vitro antibacterial potential of ripe fruits of Aegle Marmelos. Int J Pharm Pharm Sci 4: 179-181.

7. Bauer AW, Kirby WM, Sherris JC, Turck M (1966) Antibiotic susceptibility testing by a standardized single disk method. Am J Clin Pathol 45: 493-496.

8. Omar AM, Emdadul MH, Nurul I (2010) Antibacterial and larvicidal potentials of Derris indica (Lamk) Bennet. extractives. University Journal of Zoology, Rajshahi University 29.

9. Chetan S, Kamal RA, Ramkrashan K, Ashish A (2012) Antimicrobial potential of Terminalia chebula Retz. Fruit extracts against ear pathogens. World J Otorhinolaryngo 2: 8-13.

10. Mann A, Banso A, Clifford LC (2008) An antifungal property of crude plant extracts from Anogeissus leiocarpus and Terminalia Avicennioides. Tanzan J Health Res 10: 34-38.

11. Akyala IA, David I, Simon A (2013) Phytochemical screening and antibacterial activity of Gmelina arborea fruit extracts. IJMIR 1: 026-031.

12. Sripanidkulchai B, Tattawasart U, Laupattarakasem P, Wongpanich V (2002) Anti-inflammatory and bactericidal properties of selected indigenous medicinal plants used for dysuria. Thai J Pharm Sci 26: 33-38. 